\title{
Firm leadership and the gender pay gap: do active owners discriminate more than hired managers?
}

\author{
Boris Hirsch • Steffen Mueller
}

Published online: 30 July 2013

(C) Institut für Arbeitsmarkt- und Berufsforschung 2013

\begin{abstract}
Using a large linked employer-employee data set for Germany, we investigate differences in the unexplained gender pay gap between owner-run and manager-run firms. We hypothesise that owner-managers and hired managers differ in their discretion to engage in profit-reducing taste discrimination against women, which would translate into different pay gaps depending on leadership regime. We find that unexplained gaps are significantly higher in owner-run firms, both statistically and economically. Yet, scrutinising these results by restricting our analysis to firms that only differ in leadership regime, this substantial difference disappears. Therefore, our findings do not support that active owners are more discriminatory per se.
\end{abstract}

Zusammenfassung Auf Grundlage eines großen kombinierten Arbeitgeber-Arbeitnehmer-Datensatzes für Deutschland untersuchen wir Unterschiede im unerklärten geschlechtsspezifischen Lohndifferential zwischen eigentümer- und managementgeführten Unternehmen. Wir stellen die Hypothese auf, dass sich aktiven Eigentümern und angestellten Managern unterschiedliche Spielräume zur Auslebung ihrer gewinnsenkenden diskriminatorischen Präferenzen eröffnen und sich daher die Lohndifferentiale zwischen eigentümer- und managementgeführten Unternehmen unterscheiden sollten. Empirisch finden wir statistisch wie ökonomisch signifikant höhere Lohndifferentiale in eigentümergeführten Unternehmen. Die Beschränkung der Stichproben auf hinreichend ähnliche eigentümer- und managementgeführte Unternehmen lässt diese markanten Unterschiede in

Dr. B. Hirsch $(\varangle)$ · Dr. S. Mueller

Friedrich-Alexander-University Erlangen-Nürnberg, Lange Gasse 20, 90403 Nürnberg, Germany

e-mail: boris.hirsch@wiso.uni-erlangen.de den Lohndifferentialen jedoch verschwinden. Unsere Ergebnisse deuten daher nicht darauf hin, dass aktive Eigentümer per se mehr diskriminieren.

Keywords Gender pay gap · Firm leadership . Discrimination · Germany

JEL Classification J31 J J16 $\cdot$ J71

\section{Introduction}

One of the most notable stylised facts in labour economics is that women earn substantially less than men. For example, the European Commission (2010) reports an average gender gap in gross hourly earnings of about 17.6 per cent for the EU-27 countries in 2007 and 23.0 per cent for Germany. Though part of this pay differential can be attributed to gender differences in education, occupation, or work experience, a considerable part of the gender pay gap remains unexplained (see, e.g., the large meta-analysis of Weichselbaumer and Winter-Ebmer (2005) comprising more than 260 international studies between the 1960s and the 1990s). While part of this unexplained gender pay gap may simply reflect differences in human capital or occupational segregation not controlled for, part of it may also reflect discrimination against women.

Theoretical attempts of explaining this sort of wage discrimination typically take up Becker's (1971) concept of employer discrimination due to distaste. In this framework, discriminatory employers are prejudiced against women and offer lower wages to women compared to equally productive men, giving rise to an unexplained gender pay gap in the sense given above. Since non-discriminatory employers employ more women at wages below their productivity, 
discriminating employers forego profits and discrimination comes at a competitive disadvantage. Discriminatory employers thus pay for discrimination.

Up to now, there is only little empirical research on how the characteristics of firm leaders influence the gender pay gap, though they are likely to reflect firm leaders' possible discriminatory preferences and thus their discriminatory behaviour. While there has been some research on the effect of the sex of firm leaders (e.g., Cardoso and WinterEbmer 2010; Hirsch 2013), there exists-to the best of our knowledge-no piece of evidence on differences in the gender pay gap between owner-run and manager-run firms. This comes at a surprise because, as we shall argue later on, active owners and hired managers can be expected to live out their costly discriminatory preferences to a different extent depending on how strong firm profits drive firm leaders' actions. Whereas owner-managers may unopposedly pay for discrimination, owners should be less fond of costly tastebased discrimination if ownership and control are separated. Yet, agency problems may allow hired managers to indulge their tastes at such low personal costs that they even discriminate more against women than owner-managers. Using linked employer-employee data for Germany, this paper investigates for the first time whether the unexplained gender pay gap in owner-run firms differs from that in manager-run firms.

The remainder of this paper is organised as follows: Sect. 2 develops our hypothesis in more detail and reviews some related empirical literature. Section 3 describes our data set. Section 4 presents and discusses our results, and Sect. 5 concludes.

\section{Theoretical considerations and review of some related literature}

\subsection{Firm leaders' discriminatory preferences, the gender pay gap, and firm profits}

The standard approach to gender wage discrimination in the labour market originates in the pathbreaking work by Becker (1971). According to Becker, discrimination stems from personal prejudices which constitute tastes for discrimination among employers, coworkers, or costumers. As a case in point, employers may possess discriminatory preferences against female workers constituting a disutility from the employment of women. Thus, to be compensated for the loss in utility following from the employment of women discriminatory employers pay lower wages to equally productive women than to their male counterparts.

In equilibrium (absent complete segregation), all employed female workers receive the same wage, albeit lower than the wage earned by men, irrespectively of whether they work for an employer with or without discriminatory preferences. It is of prime importance, however, to note that discrimination comes at a cost in this framework. Non-discriminating employers gain a competitive advantage over their discriminating competitors by employing more women at below-productivity wages (see Arrow 1973). Discriminating employers thus trade off their profits with their taste for discrimination and decide to pay for discrimination. Put differently, instead of maximising his income available for household consumption the utility-maximising employer with discriminatory preferences chooses to devote some of his income to on-the-job consumption. Discriminating employers should therefore incur lower profits than their non-discriminating competitors, which is also found empirically (cf. Hellerstein et al. 2002; Kawaguchi 2007; Heyman et al. 2013). Related to these findings, there exists also evidence that gender wage discrimination is lower if competitive forces are stronger (see, e.g., Winter-Ebmer 1995; Black and Strahan 2001; Zweimüller et al. 2008; Hirsch et al. 2012), suggesting that employers are less able to indulge costly taste-based discrimination in a competitive environment.

In Becker's (1971) standard approach, the gender pay gap is the same in discriminatory and non-discriminatory firms. This holds because employees can instantaneously and costlessly switch employers. Once one builds in some forces hindering workers' mobility, though, things change. For instance, Bowlus and Eckstein (2002) incorporate discriminatory employer preferences into Mortensen's (1990) equilibrium search model with on-the-job search. They show that employers with more pronounced discriminatory preferences offer lower wages to women than employers with a less pronounced taste for discrimination and also make lower profits. Intuitively, the argument can be put as follows: By offering higher wages to them, less discriminatory employers can poach some women from more discriminatory firms thereby increasing their female workforce. Yet, due to search frictions, they are able to set wage offers below marginal revenue product and such low that they earn higher profits than their more discriminatory competitors. The latter still employ those women who have, by chance, not received attractive outside offers. Since search frictions provide firms with some monopsony power, more discriminatory employers with reduced profits survive in the long run as do differences in the gender pay gap across firms.

In Bowlus and Eckstein's (2002) model, firm leaders' discriminatory preferences therefore directly translate into firm-specific gender pay gaps where profits are lower in more discriminatory firms. As a corollary, we can expect that the degree of discrimination depends on the constraints firm leaders face when living out their costly discriminatory preferences. 


\subsection{Leadership regime and taste-based discrimination}

Firm leaders' discretion to actually pay for discrimination is likely to differ depending on whether firm leadership and ownership coincide. On the one hand, one may argue that owner-leaders have more discretion in trading off profits with on-the-job consumption and owner-run firms should thus discriminate more against women. A classic elaboration of this argument in the context of taste discrimination has been given by Demsetz (1983, pp. 381/382):

'Consider an owner-manager who delights in associating with people of his religion or of his skin colour. Because he spends most of his waking hours on the job, this is where he will choose to indulge his preferences. If, to indulge his taste for on-the-job consumption, he must employ workers who are less productive in supplying the goods that he sells to others, then consuming in the firm will force him to accept lower pecuniary returns. For him, this may be superior to higher income and less preferred on-the-job associations. Imagine now that this same person becomes specialised to the task of owning, not managing, the firm. Let us suppose that the professional managers that he employs to replace him in the firm's management share his tastes in fellow workers. In his new role as specialised owner, however, he derives no utility from the composition of the labour force, for he no longer puts in time at the office. He prefers instead the higher pecuniary returns that can be had with a less homogeneous mixture of labourers. His desire for profit now leads him to search for a management that is less prone to discriminate by religion and colour. [...] The net result of his becoming a specialised owner, therefore, may very well be a reduction in on-the-jobconsumption.'

On the other hand, Demsetz (1983, p. 382) qualifies that 'we can expect that specialised ownership, in and of itself, creates pressure for less on-the-job consumption so long as monitoring cost is not a barrier to guaranteeing that what is promised by management is what is delivered'. In other words, this argument only holds if agency problems are not big enough to allow hired managers to consume on the job at the detriment of the firm's profits but not their own income. In a similar vein, Ashenfelter and Hannan (1986, pp. 154155) argue that 'the capital market and the market for managerial services [may] punish deviations from profit maximisation only imperfectly. Since managers under these circumstances, if unchecked by owners, forgo little or no monetary income in exchange for the benefits of increased discrimination, they may choose to discriminate at levels above that deemed optimal by the owners.'

It is therefore an ex ante open question whether on-thejob consumption of firm leaders is higher in manager-run than in owner-run firms. Nonetheless, there are some observations suggesting that it may be larger in owner-run firms: First, there is a literature stressing the importance of non-pecuniary motives for self-employed like autonomy and self-fulfilment (e.g., Benz 2009) and showing thatconsistent with the trade-off between on-the-job consumption and income-self-employed have higher job satisfaction and lower pay, ceteris paribus (e.g., Hamilton 2000; Benz and Frey 2008). Related to this point, it seems plausible to presume that individuals with strong tastes are more likely to start their own business to have a better chance of indulging their preferences. Second, as agency problems are well-known at least since the classic work of Berle and Means (1932), many mechanisms have evolved to alleviate agency problems and thus hired managers' on-the-job consumption. As Murphy (1999) documents, nowadays most managers' pay schemes not only consist of a base salary but also contain an annual bonus depending on accounting performance, stock options, and long-term incentive plans, thereby tying managers' income closely to firm profitability. ${ }^{1}$ Furthermore, firm performance also serves as a signal on the managerial labour market, so that this kind of a reputation effect also limits managers' scope for on-thejob consumption (e.g., Demsetz 1983; Lazear 1995, p. 73). Third, there is also some piece of evidence suggesting that manager-run firms are more concerned with maximising profits than owner-run (cf. Vroom and McCann 2010).

In sum, it is an open question whether discrimination as one component of firm leaders' on-the-job consumption is more pronounced in owner-run or manager-run firms, with sound arguments for both directions. In the following, we shall address this question empirically by using a large linked employer-employee data set for Germany, which we will describe next.

\section{Data}

The data set utilised in the subsequent empirical analysis is the German LIAB, i.e. the Linked Employer-Employee Data Set of the Institute for Employment Research (Institut für Arbeitsmarkt- und Berufsforschung, IAB) of the German Federal Employment Agency (Bundesagentur für Arbeit). The LIAB is created by linking the administrative personspecific data of the IAB with the IAB Establishment Panel (cf. Alda et al. 2005). Using the LIAB, we are therefore able to control both for worker and establishment characteristics.

\footnotetext{
${ }^{1}$ Of course, all these instruments just lead to a second-best solution with lower profits than in the first best. Yet, they nevertheless direct hired managers' incentives away from costly taste discrimination towards profit maximisation. For example, Méon and Szafarz (2011) show that performance-based contracts may decrease hired managers' propensity to taste-discriminate and thus their on-the-job consumption.
} 
The employee history used for constructing the LIAB is based on the integrated notification procedure for the health, pension, and unemployment insurances. ${ }^{2}$ This procedure requires all employers to report all information of their employees if covered by the social security system, where misreporting is legally prohibited. Notifications are compulsory at the beginning and the end of employment. Additionally, an annual report must be provided for each employee employed on the 31st December of the year. As a consequence, only those workers, salaried employees, and trainees who are covered by social security are included. Thus, among others, civil servants, self-employed, those in marginal employment, students enrolled in higher education, and family workers are not included. All in all, approximately 80 per cent of all people employed in Germany are part of the employee history.

The data include, among others things, information for every employee on the daily gross wage, censored at the social security contribution ceiling, on the employee's occupation and occupational status, and on industry. Furthermore, individual characteristics, such as age, schooling, training, sex, and nationality are contained. ${ }^{3}$ Finally, an establishment number is included which is used to link the employee history and the IAB Establishment Panel.

The employer side of our data set is given by the IAB Establishment Panel, a random sample of establishments (not companies) which employ at least one employee covered by social security at the 30th June of a year. ${ }^{4}$ Every year since 1993 (1996) the IAB Establishment Panel has surveyed plants from all industries in West (East) Germany. Response rates of units which have been interviewed repeatedly exceed 80 per cent. Questions deal, among other things, with the number of employees, the establishment's commitment to collective agreements, the existence of a works council, the plant's performance and export share, and its technological status. What is more, for the first time in 2007 the survey included a question concerning plant leadership, i.e. whether the establishment is entirely manager-run, entirely owner-run, or run both by hired managers and owners, thus allowing us to investigate whether the unexplained gender gap differs across plants with different leadership regimes.

Linking both the IAB Establishment Panel and the employee history gives the LIAB. We will use the 2007 wave

\footnotetext{
${ }^{2}$ Details are given by Alda et al. (2005) and Bender et al. (2000).

${ }^{3}$ Due to notifications made in the case of changes in the employment status that are relevant according to benefit entitlement rules, there is also information on the employee's marital status and the number of children at the time the change takes place. However, these variables contain much measurement error and are very fragmentary, so that we will not be able to use them.

${ }^{4}$ Details about the IAB Establishment Panel are given by Kölling (2000) and Fischer et al. (2009).
}

of the LIAB cross-sectional model, which contains both information on individuals and IAB Panel establishments matched as of the 30th of June this year. This enables us to investigate differences in the unexplained gender pay gap between owner-run and manager-run plants controlling for a large variety of individual and establishment characteristics. ${ }^{5}$ Since we have no detailed information on the number of hours worked but just a qualitative variable distinguishing between full-time and two sorts of part-time work, we restrict our analysis to full-time employees. We further exclude workers working for establishments in the public sector where the distinction between owner-run and managerrun plants is not applicable. This leaves us-after dropping observations with missing values of the subsequently included regressors-with observations for 274,399 $(66,249)$ men and 68,280 $(28,249)$ women working for 3,620 $(2,633)$ West (East) German establishments, 2,411 $(1,955)$ of which are owner-run and 1,179 (678) manager-run. Descriptive statistics of our West German and East German samples and the variables included in further analyses are presented Table 5 in the Appendix.

A shortcoming of the LIAB is that daily gross wages are censored at the social security contribution ceiling, viz. $€ 172.60$ in West Germany and $€ 149.59$ in East Germany in 2007. This affects 23.7 per cent of West German and 7.6 per cent of East German observations. Obviously, using the wage data without any correction may result in misleading estimates. To deal with the problem of censored wages, we impute wages above these thresholds. ${ }^{6}$ Assuming that daily gross wages follow a log-normal distribution, which seems to be a plausible approximation, we apply the singleimputation procedure proposed by Gartner (2005). In a first step, we estimate Tobit models for each combination of gender and leadership regime (e.g., for females employed in owner-run plants) separately for our East German and West German samples, where the dependent variable is the log daily gross wage and the regressors are those included in the further analysis. In a second step, for every censored observation a random value is drawn from a normal distribution left-truncated at the respective social security contribution ceiling with predicted log wage as mean and standard deviation as estimated from the Tobit models. ${ }^{7}$

\footnotetext{
${ }^{5}$ In the following, we shall not discuss results for establishments jointly run by hired managers and owners because we do not know the relative influence of either groups in the plant's management. Note, however, that in general the results for these plants are in between those gained for entirely owner-run and entirely manager-run establishments, which is in line with our expectation that they should constitute an intermediate case between these two extremes (see also footnote 15).

${ }^{6}$ Note also that we exclude observations with very low daily wages of $€ 20$ or less implying a gross monthly wage of $€ 600$ or less.

${ }^{7}$ Note that all our following results also show up when restricting the West German and the East German samples to uncensored wage obser-
} 


\section{Results}

As a starting point, we present some descriptive evidence for our West and East German samples (see Table 5 in the Appendix). First of all, in West Germany average daily gross wages are $26.7 \mathrm{log}$ points lower for women than for men. Interestingly, this raw gender differential amounts to $31.3 \mathrm{log}$ points in owner-run, but just $24.4 \mathrm{log}$ points in managerrun plants. Though the raw gap is markedly lower in East Germany independently of the leadership regime, the difference between owner-run and manager-run plants is rather similar to the one in West Germany: In East Germany, we find an overall raw differential of $13.9 \log$ points, which is again markedly higher in owner-run (20.7 log points) as opposed to manager-run plants $\left(12.0 \mathrm{log}\right.$ points). ${ }^{8}$ Thus, the descriptive evidence suggests that owner-run firms discriminate more than manager-run.

Empirically, however, these raw gender pay differentials are of limited information as they neglect individual and establishment heterogeneity, such as gender differences in human capital endowments and differences in the gender composition of the workforce or the establishment size between owner-run and manager-run plants. In order to deal with observed heterogeneity, we will in the following apply the standard Oaxaca-Blinder (OB) decomposition to estimate the unexplained gender pay gaps. Based on separate earnings functions for female and male workers including several control variables for individual and plant characteristics, this method decomposes the observed average pay gap into an 'explained' part due to differences in average characteristics/endowments and an 'unexplained' part due to differences in coefficients, typically referred to as 'discrimination'. Hence,

$\overline{\ln }_{m}-\overline{\ln w}_{f}=\left(\overline{\boldsymbol{x}}_{m}-\overline{\boldsymbol{x}}_{f}\right)^{\top} \boldsymbol{\beta}_{m}+\left(\boldsymbol{\beta}_{m}-\boldsymbol{\beta}_{f}\right)^{\top} \overline{\boldsymbol{x}}_{f}$

with the $\log$ wage $\ln w$, the characteristics included in the earnings functions $\boldsymbol{x}$, and their coefficients $\boldsymbol{\beta}$, where the indices $f$ and $m$ denote female and male, respectively, and the bars group averages. ${ }^{9}$

vations or young low-skilled and medium-skilled workers, for whom censoring does not play any role. Given this robustness of our findings, we conclude that they are not driven by our imputation mechanism.

${ }^{8}$ The lower pay gap for East Germany compared to West Germany is a finding familiar from the relevant literature (cf., e.g., Maier 2007).

${ }^{9}$ Note that the way of decomposing the gender pay gap given in (1) assumes men to have the non-discriminatory wage structure by calculating the explained gender pay based on male workers' coefficients. While this seems intuitively appealing (since we think primarily as women being underpaid relative to men rather than men being overpaid relative to women), the way how the $\mathrm{OB}$ decomposition is carried out comes at some arbitrariness. For instance, rather than choosing men as reference category one could use women instead, yielding

$\overline{\ln }_{m}-\overline{\ln w}_{f}=\left(\overline{\boldsymbol{x}}_{m}-\overline{\boldsymbol{x}}_{f}\right)^{\top} \boldsymbol{\beta}_{f}+\left(\boldsymbol{\beta}_{m}-\boldsymbol{\beta}_{f}\right)^{\top} \overline{\boldsymbol{x}}_{m}$,
We will carry out OB decompositions as given in (1) separately for manager-run and owner-run plants obtaining one unexplained gender pay gap for the group of workers employed at owner-run plants and one for those working in manager-run plants. We will then compare the two gaps and check whether their confidence intervals overlap. As control variables we first of all include standard individual characteristics, i.e. potential experience (linearly and squared), tenure (linearly and squared), a dummy for non-German nationality, a group of six education dummies ${ }^{10}$ and a group of nine occupation dummies. ${ }^{11} \mathrm{Next}$, we include several plant characteristics found to matter for unexplained pay gaps in earlier studies using the LIAB data (cf., e.g., Achatz et al. 2005; Heinze and Wolf 2010; Beblo et al. 2011): the log of establishment size, ${ }^{12}$ a dummy for works council existence, two dummies for the presence of a collective agreement either at the sector or the firm level, dummies for exporting activity, foreign ownership, plant location in a rural area, and new production technology, both the shares of women and qualified workers in the plant's workforce, and eight sector dummies. ${ }^{13}$

Controlling for these individual and plant characteristics is meant to account for productivity differences, segregation effects, and institutional as well as organisational factors likely to influence the gender pay gap. In particular, accounting for differences in establishment characteristics is crucial because manager-run and owner-run plants obviously differ in more dimensions than just the leadership

or use a weighted average of men's and women's coefficients to calculate the explained gap (see, e.g., the discussion in Oaxaca and Ransom 1994). Unfortunately, different decompositions generally give different results, so that one has to carefully compare the results obtained for different reference categories. Although we will in the following only report results for the $\mathrm{OB}$ decomposition with male workers as reference category (and their wage structure as the non-discriminatory reference point) as given in (1), the reader should be aware that we will only take those results at face value that also show up when applying the OB decomposition with female workers as reference category as given in (2). Above that, we will make clear when results hinge on using men as reference group.

${ }^{10}$ We distinguish seven different groups of workers: (1) workers with neither apprenticeship nor Abitur (which is the German equivalent to A-levels or graduation from high school), (2) those with only apprenticeship, (3) those with only Abitur, (4) those with both, (5) workers with a technical college degree, (6) workers with a university degree, and (7) workers with unknown education.

${ }^{11}$ We distinguish ten groups of occupations: (1) basic and (2) qualified manual occupations, (3) engineers/technicians, (4) basic and (5) qualified service occupations, (6) semi-professionals and (7) professionals, (8) basic and (9) qualified business occupations, and (10) managers.

${ }^{12}$ Allowing for a more flexible specification of plant size (either linearquadratic or a group of dummy variable) does not change our results.

${ }^{13}$ Sectors are (1) agriculture, hunting, and forestry (including fishing), (2) mining, quarrying, electricity, gas, and water supply, (3) manufacturing, (4) trade and repair, (5) construction, (6) transport, storage, and communication, (7) financial intermediation, (8) business activities, and (9) other activities. 
Table 1 Plant characteristics by leadership (whole sample; means)

\begin{tabular}{|c|c|c|c|c|}
\hline \multirow[t]{2}{*}{ Variable } & \multicolumn{2}{|c|}{ West Germany } & \multicolumn{2}{|c|}{ East Germany } \\
\hline & Owner-run & Manager-run & Owner-run & Manager-run \\
\hline Establishment size & 54.689 & $510.110[0.000]$ & 31.621 & $167.610[0.000]$ \\
\hline Collective agreement at sector level (dummy) & 0.418 & $0.588[0.000]$ & 0.195 & $0.403[0.000]$ \\
\hline Collective agreement at firm level (dummy) & 0.030 & $0.118[0.000]$ & 0.049 & $0.177[0.000]$ \\
\hline Works council (dummy) & 0.107 & $0.692[0.000]$ & 0.057 & $0.545[0.000]$ \\
\hline Exporter (dummy) & 0.232 & $0.400[0.000]$ & 0.186 & $0.334[0.000]$ \\
\hline Foreign ownership (dummy) & 0.008 & $0.177[0.000]$ & 0.007 & $0.116[0.000]$ \\
\hline New production technology (dummy) & 0.692 & $0.734[0.010]$ & 0.685 & $0.718[0.111]$ \\
\hline Proportion of female workers & 0.392 & $0.358[0.001]$ & 0.359 & $0.362[0.829]$ \\
\hline Proportion of qualified workers & 0.777 & $0.776[0.932]$ & 0.895 & $0.881[0.133]$ \\
\hline Plant located in rural area (dummy) & 0.211 & $0.175[0.011]$ & 0.469 & $0.395[0.001]$ \\
\hline Agriculture, hunting, forestry (dummy) & 0.022 & $0.005[0.000]$ & 0.028 & $0.025[0.688]$ \\
\hline Mining, quarrying, electricity, gas, water (dummy) & 0.007 & $0.052[0.000]$ & 0.005 & $0.036[0.000]$ \\
\hline Manufacturing (dummy) & 0.251 & $0.349[0.000]$ & 0.404 & $0.416[0.596]$ \\
\hline Trade and repair (dummy) & 0.215 & $0.185[0.041]$ & 0.147 & $0.119[0.074]$ \\
\hline Construction (dummy) & 0.146 & $0.019[0.000]$ & 0.138 & $0.046[0.000]$ \\
\hline Transport, storage, communication (dummy) & 0.040 & $0.070[0.000]$ & 0.036 & $0.055[0.031]$ \\
\hline Financial intermediation (dummy) & 0.007 & $0.040[0.000]$ & 0.007 & $0.013[0.137]$ \\
\hline Business activities (dummy) & 0.159 & $0.145[0.268]$ & 0.105 & $0.138[0.020]$ \\
\hline Other activities (dummy) & 0.154 & $0.135[0.131]$ & 0.130 & $0.152[0.152]$ \\
\hline Number of plants & 2,431 & 1,176 & 1,951 & 673 \\
\hline
\end{tabular}

Notes: The data set used is the LIAB cross-sectional model for the year 2007. The $p$-values for $t$-tests of the hypothesis that there are no group differences are reported in squared brackets

regime (see Table 1, which presents descriptive statistics for the plants in our sample by leadership regime). For instance, manager-run plants are much larger, are more often covered by collective agreements, and much more frequently have a works council. Not controlling for these differences may easily result in a spurious correlation between the gender pay gap and leadership regime driven by other plant characteristics. ${ }^{14}$ For example, part of the gender pay gap could simply reflect the well-known employer size-wage effect (e.g., Oi and Idson 1999) if more men are working in betterpaying large plants.

The unexplained gender pay gaps in manager-run and owner-run plants following from decomposing the gender pay gap according to (1) are reported in Table 2. While they turn out to be substantially lower than the raw gaps in West Germany, they are even slightly larger than the raw gaps in East Germany. But interestingly, the differences in the un-

\footnotetext{
${ }^{14}$ Note that we do not control for profitability because our theoretical considerations imply that plants that discriminate to a greater extent against women are for this reason less profitable. Hence, conditioning on profitability might take away part of the unexplained pay gap due to differences in discriminatory behaviour. Nonetheless, including a dummy for positive profits in our OB decompositions left our results virtually unchanged.
}

explained gaps between manager-run and owner-run plants are even more pronounced than those found descriptively. In West Germany, the unexplained gender pay gap is $28.7 \mathrm{log}$ points in owner-run, but only $16.4 \mathrm{log}$ points in manager-run establishments, resulting in a marked difference of $12.3 \mathrm{log}$ points. While the unexplained gender pay gaps are (at least slightly) lower in East Germany-24.3 log points in ownerrun and $14.3 \log$ points in manager-run establishments- the leadership difference (10.0 log points) is similar to the one found in West Germany. ${ }^{15}$ In both cases, the 95 per cent confidence intervals of the unexplained pay gaps do not overlap, so that we conclude that the difference is not only relevant from an economic point of view, but also statistically significant. $^{16}$

\footnotetext{
${ }^{15}$ As discussed in footnote 5 , the results for workers employed by the group of plants which are jointly run by hired managers and active owners are in between those results reported for entirely manager-run and owner-run plants: In West Germany, the unexplained gender pay gaps in this category of plants amounts to $22.0 \mathrm{log}$ points (standard error $1.6 \log$ points) and $18.0 \log$ points (standard error $2.0 \log$ points) in East Germany.

${ }^{16}$ We should, however, emphasise that the difference in East Germany is reduced to just $3.6 \log$ points when carrying out $\mathrm{OB}$ decompositions with women as reference group rather than men, whilst the difference
} 
Table 2 Unexplained gender pay gaps obtained from separate Oaxaca-Blinder decompositions for workers employed by manager-run and owner-run plants (whole sample; in log points)

\begin{tabular}{llll}
\hline & Overall & Owner-run & Manager-run \\
\hline West Germany & $19.0(1.1)$ & $28.7(1.3)$ & $16.4(1.1)$ \\
& {$[16.9,21.1]$} & {$[26.2,31.3]$} & {$[14.3,18.4]$} \\
East Germany & $17.9(1.2)$ & $24.3(2.0)$ & $14.3(1.3)$ \\
& {$[15.5,20.2]$} & {$[20.4,28.3]$} & {$[11.8,16.8]$} \\
\hline
\end{tabular}

Notes: The data set used is the LIAB cross-sectional model for the year 2007. Standard errors clustered at the plant level are given in parentheses followed from 95 per cent confidence intervals. Control variables included are: experience, experience squared, tenure, tenure squared, six education dummies, nine occupation dummies, a dummy for nonGerman nationality, log establishment size, dummies for works council existence, a collective agreement at firm (sector) level, exporting activity, foreign ownership, plant location in a rural area, new production technology, the shares of women and qualified workers in the plant's workplace, and eight sector dummies

Since at least part of the unexplained gender pay gap should represent wage discrimination against females, the more pronounced unexplained gap in owner-run plants may mirror owners' greater discretion in living out their possible discriminatory preferences compared to hired managers. Yet, just comparing unexplained gender gaps between manager-run and owner-run plants may be misleading, even when controlling for other observed plant characteristics, for at least two reasons: Firstly, there are likely to be differences in unobserved plant characteristics that may themselves affect the unexplained gap independently of the leadership regime. Just to give one example, owner-run plants may offer a different work environment especially valued by women such as flexible working hours, so that part of the unexplained gap may actually reflect compensating wage differentials. Not accounting for these unobserved plant characteristics may therefore introduce a spurious correlation between leadership regime and the unexplained gap if these omitted variables are systematically related to plant leadership.

Secondly, there may exist self-selection of workers with different unobserved characteristics, like motivation, career outlook, or mobility, into plants with different characteristics, such as larger establishments with more elaborate hierarchies and thus improved career opportunities. As women and men have been found to differ considerably in career aspirations and job mobility (e.g., Chevalier 2007; Hirsch and Schnabel 2012), this sort of self-selection would invalidate the comparison of unexplained pay gaps across

in West Germany still amounts to $12.3 \log$ points in this case. Hence, the difference in East Germany is neither economically nor statistically significant when changing the reference group. owner-run and manager-run plants unless one accounts for these self-selection effects.

Together, these arguments cast some doubt on whether the differences in unexplained gender gaps between managerrun and owner-run plants found above should be really attributed to different leadership regimes or rather to other factors-or, put differently, whether just comparing the unexplained gap for all owner-run plants with the gap for all manager-run runs the risk of comparing apples and oranges. In a next step, we therefore restrict our analysis to sufficiently similar manager-run and owner-run plants, in the sense that these plants show undistinguishable observed characteristics. Estimating unexplained gaps only for workers in this restricted sample should sidestep the problem of self-selection of workers due to observed plant characteristics. Furthermore, this should also mitigate the problems of different unobserved establishment characteristics, likely to be correlated with plants' observed characteristics, and selfselection of workers due to these unobserved characteristics.

To arrive at samples of workers working for plants that only differ with respect to their leadership regime but not with respect to other observed characteristics, we construct a sample of similar owner-run and manager-run establishments. This is achieved via radius propensity score matching using only the nearest neighbour without replacement: That is, for every owner-run plant we look for a single statistical twin among manager-run plants that does not differ significantly in those observable characteristics included in the wage regressions. ${ }^{17}$ The propensity score is obtained from a probit model for the probability that a plant is owner-run including all the plant characteristics that entered the $\mathrm{OB}$ decompositions as regressors. After applying this procedure separately for East and West Germany, we are left with a sample of 30,442 $(13,648)$ employees working for $505(382)$ owner-run plants and 33,135 $(15,365)$ employees working for the same number of manager-run plants in West (East) Germany. Note that these plants indeed show no significant differences in observable characteristics, as can be seen from the descriptive statistics presented in Table 3.

The unexplained gender pay gaps for workers working in the manager-run and owner-run establishments included in our matched samples are reported in Table 4. While the difference is reduced markedly to just $3.8 \log$ points in West Germany, it even changes sign in East Germany. ${ }^{18}$ Furthermore, both differences are now statistically insignificant as confidence intervals clearly overlap.

\footnotetext{
${ }^{17}$ Ideally, we would like to get rid of self-selection biases by comparing unexplained pay gaps in owner-run and manager-run plants that are indistinguishable to a potential worker choosing his or her employer. By matching on observed establishment characteristics we hope to come as close as possible to this comparison, although we are aware that unobserved differences across both types of plants may still exist.

${ }^{18}$ Interestingly, in the matched West German sample the raw pay differential is even higher in manager-run compared to owner-run firms.
} 
Table 3 Plant characteristics by leadership (matched sample; means)

\begin{tabular}{|c|c|c|c|c|}
\hline \multirow[t]{2}{*}{ Variable } & \multicolumn{2}{|c|}{ West Germany } & \multicolumn{2}{|c|}{ East Germany } \\
\hline & Owner-run & Manager-run & Owner-run & Manager-run \\
\hline Establishment size & 142.200 & $149.810[0.698]$ & 74.319 & $79.984[0.574]$ \\
\hline Collective agreement at sector level (dummy) & 0.491 & $0.471[0.529]$ & 0.301 & $0.301[1.000]$ \\
\hline Collective agreement at firm level (dummy) & 0.059 & $0.071[0.445]$ & 0.128 & $0.105[0.311]$ \\
\hline Works council (dummy) & 0.422 & $0.384[0.223]$ & 0.262 & $0.275[0.684]$ \\
\hline Exporter (dummy) & 0.360 & $0.329[0.290]$ & 0.322 & $0.275[0.155]$ \\
\hline Foreign ownership (dummy) & 0.036 & $0.034[0.864]$ & 0.031 & $0.034[0.839]$ \\
\hline New production technology (dummy) & 0.721 & $0.705[0.578]$ & 0.696 & $0.709[0.693]$ \\
\hline Proportion of female workers & 0.370 & $0.392[0.204]$ & 0.365 & $0.365[0.973]$ \\
\hline Proportion of qualified workers & 0.740 & $0.755[0.396]$ & 0.862 & $0.872[0.565]$ \\
\hline Plant located in rural area (dummy) & 0.196 & $0.202[0.813]$ & 0.427 & $0.421[0.884]$ \\
\hline Agriculture, hunting, forestry (dummy) & 0.014 & $0.010[0.562]$ & 0.045 & $0.042[0.859]$ \\
\hline Mining, quarrying, electricity, gas, water (dummy) & 0.018 & $0.026[0.389]$ & 0.021 & $0.018[0.795]$ \\
\hline Manufacturing (dummy) & 0.315 & $0.277[0.191]$ & 0.369 & $0.374[0.881]$ \\
\hline Trade and repair (dummy) & 0.196 & $0.224[0.280]$ & 0.131 & $0.141[0.674]$ \\
\hline Construction (dummy) & 0.032 & $0.034[0.860]$ & 0.060 & $0.068[0.658]$ \\
\hline Transport, storage, communication (dummy) & 0.065 & $0.050[0.280]$ & 0.047 & $0.052[0.740]$ \\
\hline Financial intermediation (dummy) & 0.016 & $0.016[1.000]$ & 0.005 & $0.013[0.255]$ \\
\hline Business activities (dummy) & 0.117 & $0.118[0.685]$ & 0.160 & $0.141[0.479]$ \\
\hline Other activities (dummy) & 0.166 & $0.176[0.677]$ & 0.162 & $0.149[0.618]$ \\
\hline Number of plants & 505 & 505 & 382 & 382 \\
\hline
\end{tabular}

Notes: The data set used is the LIAB cross-sectional model for the year 2007. The $p$-values for $t$-tests of the hypothesis that there are no group differences are reported in squared brackets

Table 4 Unexplained gender pay gaps obtained from separate Oaxaca-Blinder decompositions for workers employed by manager- and owner-run plants (matched sample; matching on all plant characteristics; in $\log$ points)

\begin{tabular}{llll}
\hline & Overall & Owner-run & Manager-run \\
\hline West Germany & $23.2(1.2)$ & $25.0(1.6)$ & $21.2(1.4)$ \\
& {$[20.9,25.5]$} & {$[21.8,28.2]$} & {$[18.5,23.9]$} \\
East Germany & $21.5(1.7)$ & $19.3(3.7)$ & $20.2(1.7)$ \\
& {$[18.1,24.9]$} & {$[12.1,26.6]$} & {$[16.9,23.6]$} \\
\hline
\end{tabular}

Notes: The data set used is the LIAB cross-sectional model for the year 2007. Standard errors clustered at the plant level are given in parentheses followed from 95 per cent confidence intervals. Control variables included are those reported in the notes of Table 2

Overall, we conclude that there are no significant differences in unexplained gaps across plants that only differ in their leadership regimes but have otherwise similar characteristics. While we found clear evidence that unexplained pay gaps are markedly lower in manager-run than in owner-run plants, a more detailed look at sufficiently similar establishments thus casts serious doubt on this being actually due to plants' different leadership regimes. Rather, our evidence suggests that self-selection of workers with different unobserved characteristics into manager-run and owner-run establishments and/or different unobserved characteristics across those establishments drive our findings. ${ }^{19}$ Hence, it would be unjustified to attribute the marked differences found in the full samples to the leadership regime, and our results are out of tune with the notion that women face more wage discrimination in owner-run plants due to owners' higher discretion in living out discriminatory preferences compared to hired managers.

Instead of matching both types of plants on all establishment characteristics, it is instructive to have a closer look at those characteristics likely to drive the marked reduction in the difference of the unexplained gender pay gaps across owner-run and manager-run plants. As Table 1 documents, the most obvious difference between both types is plant size-with manager-run plants being more than nine times as large as owner-run in West Germany and more than five times as large in East Germany. To gauge the importance of plant size for our findings, we also re-did our analysis for

\footnotetext{
${ }^{19}$ As noted by a referee, our results could also mirror self-selection of workers with different observed characteristics that are differently valued in manager-run and owner-run plants.
} 
matched samples where matching is on plant size only (using the same matching procedure as described above) the results of which are given in Table 6 in the Appendix. For West Germany the difference in the unexplained gaps is reduced by 26 per cent to $9.1 \log$ points, while for East Germany the reduction amounts to 45 per cent leaving a difference of 5.5 $\log$ points. While this suggests that plant size is an important determinant of workers' self selection, other factors seem to be important as well and matching on all establishment characteristics is necessary to minimise selection effects.

\section{Conclusions}

In this paper, we have investigated whether the gender pay gap is different in owner-run as opposed to manager-run firms. Theoretically, we followed Becker's (1971) classic argument that personal prejudices may constitute a taste for discrimination against women. Since discrimination comes at a cost in this framework, the extent of discrimination crucially depends on the firm leaders' discretion in trading off firm's profits with their taste for discrimination. We followed Demsetz's (1983) argument that, absent any monitoring costs, owner-managers can be expected to consume more on the job (by discriminating against women) than hired managers who will be effectively tied to profit maximisation by their principals. As soon as monitoring costs and thus agency problems come into play, however, also hired managers are able to live out their costly preferences to some extent. If the manager's income only marginally depends on the cost of taste discrimination, it is even possible to arrive at more discrimination in manager-run firms. Therefore, the impact of leadership regime on gender wage discrimination is open ex ante.

Using a large linked employer-employee data set for Germany, we indeed found that raw pay differentials are markedly larger in owner-run compared to manager-run plants in both West and East Germany. In separate OaxacaBlinder decompositions for workers employed by owner-run and those working for manager-run plants controlling for a large variety of worker and plant characteristics we also arrive at unexplained pay gaps that are significantly larger in owner-run establishments. Yet, noting the marked differences in characteristics between manager-run and ownerrun establishments we then argued that these differences in the pay gaps may not be driven by the different leadership regime per se but by unobserved plant characteristics and self-selection of workers into establishments with different observed and/or unobserved characteristics. In order to meet these concerns-at least to some extent-we then repeated our analysis using samples of manager-run and owner-run establishments that do not differ in observed characteristics. In these matched samples for West and East Germany, no significant differences in unexplained pay gaps between manager-run and owner-run plants showed up. From these results, we conclude that the significant and large differences in the unexplained gender pay gap between owner-run and manager-run plants found are not driven by the plants' leadership regime.

\section{Executive summary}

There is ample evidence that women earn substantially less than men and that part of this gender pay gap is due to discrimination against women. Theoretical attempts of explaining gender wage discrimination typically follow Becker's (1971) classic approach of taste-based employer discrimination. In this setting, discriminatory employers are prejudiced against women and lose in utility when employing them. To be compensated for this loss in utility, discriminatory employers pay lower wages to women than to men giving rise to a gender pay gap that is unrelated to worker productivity. Yet, taste-based discrimination comes at a competitive disadvantage because non-discriminatory firms employ more women at below-productivity wages and thus make larger profits.

What is crucial for taste-based discrimination to appear is that firm leaders are able to live out their costly preferences at the detriment of firms' profits. And as argued by Demsetz (1983), firm leaders' discretion in trading off profits with their taste for discrimination is likely to differ depending on whether firm leadership and ownership coincide. In owner-run firms, owner-managers may unopposedly pay for discrimination because they are also the residual claimants of profits. Things change, however, if control and ownership are separated. In firms run by hired managers, owners should be less fond of costly taste-based discrimination. If managers' actions are effectively tied to profit maximisation, manager-run firms are therefore expected to discriminate less against women than owner-run. As soon as agency problems come into play, though, also hired managers are able to live out their costly preferences to some extent. If managers' income only marginally depends on the cost of taste discrimination, it is even possible to arrive at more discrimination in manager-run firms.

Using German data from the 2007 wave of the linked employer-employee data set of the Institute for Employment Research (LIAB) we are the first to investigate whether the unexplained gender pay gap differs across owner-run and manager-run firms. Descriptively, we find that raw gender pay differentials are considerably higher in owner-run than in manager-run firms in both East and West Germany: In West Germany, full-time employed women earn 26.8 per cent less than full-time employed men in owner-run firms but just 21.7 per cent less in manager-run firms, whereas in 
East Germany the respective figures are 18.7 per cent and 11.3 per cent. This also holds when correcting for different worker and firm characteristics using Oaxaca-Blinder decompositions. In West Germany, the unexplained pay gap is 24.9 per cent in owner-run and 15.1 per cent in manager-run firms, whereas in East Germany the gap amounts to 21.6 per cent and 13.3 per cent, respectively.

Whereas these results suggest that owner-run firms are more discriminatory than manager-run, we also find that owner-run and manager-run firms considerably differ in their characteristics. For example, owner-run firms are much smaller, less often bound by collective agreements, and less frequently have a works council. This may pose a problem if workers with different motivation, career outlook, or mobility, which are unobservables in our data set, select themselves into firms with different characteristics like larger firms with more elaborate hierarchies and improved career opportunities. In particular, women and men have been shown to considerably differ in career aspirations and job mobility, so just comparing unexplained pay gaps between owner-run and manager-run firms may be misleading.

To address this problem, we redo our analysis focusing on a subsample of owner-run and manager-run firms that show indistinguishable observed characteristics, where the subsample is obtained from a propensity score matching procedure. In this subsample, the difference in the unexplained gap between manager-run and owner-run disappears. In West Germany, the unexplained pay gap is 22.1 per cent in manager-run firms and 19.1 per cent in owner-run, this difference being statistically insignificant. In East Germany, the gap is even somewhat larger in managerrun (18.3 per cent) than in owner-run firms (17.6 per cent). From these results, we conclude that the significant difference in the unexplained gender pay gap between owner-run and manager-run firms found before is not driven by firms' leadership regime per se.

\section{Kurzfassung}

Eine Vielzahl empirischer Studien dokumentiert, dass Frauen nachwievor weniger als Männer verdienen und Teil des geschlechtsspezifischen Lohndifferentials auf Lohndiskriminierung zurückgeführt werden kann. Theoretische Erklärungsansätze hierzu basieren üblicherweise auf Becker (1971) Theorie präferenzbasierter Diskriminierung seitens der Unternehmen. Unterstellt wird hierbei, dass diskriminierende Arbeitgeber Vorurteile gegenüber Frauen hegen und aus deren Beschäftigung einen Nutzenverlust ziehen. Um diesen Nutzenverlust auszugleichen, nehmen diskriminierende Arbeitgeber einen Lohnabschlag für Frauen vor, der auch bei gleicher Produktivität von Frauen und
Männern zu einem geschlechtsspezifischen Lohndifferential führt. Jedoch stellt diese Diskriminierung einen Wettbewerbsnachteil für diskriminierende Unternehmen dar, da ihre nicht-diskriminierenden Wettbewerber eine größere Zahl von Frauen zum niedrigeren Frauenlohn beschäftigen und somit höhere Gewinne erzielen.

Damit es zu präferenzbasierter Lohndiskriminierung kommen kann, muss die Unternehmensleitung in der Lage sein, ihre Präferenzen zulasten des Unternehmensgewinnes auszuleben. Und diese Möglichkeit zum Gewinnverzicht sollte mit Demsetz (1983) davon abhängen, ob Eigentum und Kontrolle in denselben Händen liegen. Während in eigentümergeführten Unternehmen die Unternehmensleitung ungehindert auf Gewinne verzichten kann, wird ein von den Eigentümern bestelltes Management auf deren Widerstand treffen, wenn es versucht, zulasten der Gewinne zu diskriminieren. Sofern die Eigentümer das Management wirksam auf Gewinnmaximierung verpflichten können, ist daher in managementgeführten Unternehmen ein geringeres Aus$\mathrm{maß}$ an Lohndiskriminierung zu erwarten. Liegen jedoch Agency-Probleme vor, so wird auch das Management seine gewinnschmälernden Präferenzen zu einem gewissen Grad ausleben können. Im Extremfall kann dies sogar zu mehr Diskriminierung in managementgeführten Betrieben führen, wenn nämlich die Einkommen der Manager nur geringfügig von den Kosten der Diskriminierung beeinflusst werden.

Auf Grundlage der 2007er-Welle des verbundenen Arbeitgeber-Arbeitnehmer-Datensatzes des Instituts für $\mathrm{Ar}$ beitsmarkt- und Berufsforschung (LIAB) für Deutschland untersuchen wir als erste, ob sich das unerklärte Geschlechterlohndifferential in eigentümer- und managementgeführten Unternehmen unterscheidet. In deskriptiven Auswertungen finden wir, dass in westdeutschen eigentümergeführten Unternehmen vollzeitbeschäftigte Frauen 26,8 Prozent weniger als vollzeitbeschäftigte Männer verdienen, während sie in managementgeführten Unternehmen lediglich 21,7 Prozent weniger erhalten. Auch für Ostdeutschland findet sich ein deutlicher Unterschied, hier betragen die Differentiale 18,7 Prozent bzw. 11,3 Prozent. Diese Differenzen zwischen eigentümer- und managementgeführten Unternehmen bleiben auch bestehen, wenn mithilfe von Oaxaca-Blinder-Zerlegungen Unterschieden in den Arbeitnehmer- wie Arbeitgebermerkmalen Rechnung getragen wird. So beträgt das unerklärte Lohndifferential 24,9 Prozent in eigentümer- und lediglich 15,1 Prozent in managementgeführten westdeutschen Unternehmen, während wir für Ostdeutschland unterklärte Differentiale von 21,6 Prozent bzw. 13,3 Prozent finden.

Während diese Ergebnisse nahelegen, dass eigentümergeführte Unternehmen stärker diskriminieren als managementgeführte, finden wir zugleich, dass sich die beiden Gruppen in ihren sonstigen Merkmalen erheblich voneinander unterscheiden. So sind eigentümergeführte Unternehmen 
im Durchschnitt erheblich kleiner, deutlich seltener tarifgebunden und besitzen wesentlich seltener einen Betriebsrat. Dies mag jedoch ein Problem darstellen, sofern sich Arbeitnehmer mit unterschiedlicher Motivation, Mobilität und Karriereaspirationen in unterschiedliche Unternehmen selektieren, z.B. große Unternehmen mit mehr Hierarchieebenen und besseren Aufstiegschancen. Da sich insbesondere Frauen und Männer hinsichtlich ihrer Jobmobilität und Karriereaspirationen deutlich voneinander unterscheiden, kann ein einfacher Vergleich von unerklärten Geschlechterlohndifferentialen zwischen eigentümer- und managementgeführten Unternehmen in die Irre führen.

Um dem Problem der Selbstselektion von Beschäftigten Rechnung $\mathrm{zu}$ tragen, wiederholen wir unsere bisherige Analyse für eine Teilstichprobe von management- und eigentümergeführten Unternehmen, die sich in ihren beobachteten Merkmalen nicht unterscheiden, wobei wir zur Konstruktion dieser Teilstichprobe ein Propensity-ScoreMatching-Verfahren nutzen. In dieser Teilstichprobe ver- schwinden die Gruppenunterschiede im unerklärten Lohndifferential: In Westdeutschland beträgt das unerklärte Differential 22,1 Prozent in eigentümer- und 19,1 Prozent in managementgeführten Unternehmen, wobei dieser Unterschied statistisch insignifikant ist, während es in ostdeutschen managementgeführten (mit 18,3 Prozent) sogar leicht größer als in eigentümergeführten Unternehmen (17,6 Prozent) ausfällt. Unsere Schlussfolgerung ist daher, dass der signifikante Unterschied im unerklärten geschlechtsspezifischen Lohndifferential zwischen eigentümer- und managementgeführten Unternehmen nicht ursächlich auf die Art der Unternehmensleitung zurückgeführt werden kann.

Acknowledgements We would like to thank Jürgen Deinhard, Regina T. Riphahn, Thorsten Schank, Claus Schnabel, Christoph Wunder, and two anonymous referees for very helpful comments and suggestions. We also appreciate comments received from participants of the 4th User Conference of the RDC of the IAB in April 2011 and of the Annual Meeting of the Verein für Socialpolitik in September 2011. 
Appendix: Tables 5 and 6

Table 5 Descriptive statistics (means)

\begin{tabular}{|c|c|c|c|c|c|c|c|c|}
\hline \multirow[t]{3}{*}{ Variable } & \multicolumn{4}{|c|}{ Owner-run } & \multicolumn{4}{|c|}{ Manager-run } \\
\hline & \multicolumn{2}{|c|}{ West Germany } & \multicolumn{2}{|c|}{ East Germany } & \multicolumn{2}{|c|}{ West Germany } & \multicolumn{2}{|c|}{ East Germany } \\
\hline & Men & Women & Men & Women & Men & Women & Men & Women \\
\hline Log wage (including imputed values) & 4.617 & 4.304 & 4.139 & 3.933 & 4.961 & 4.717 & 4.505 & 4.386 \\
\hline Censored wage observation (dummy) & 0.090 & 0.026 & 0.002 & 0.001 & 0.301 & 0.119 & 0.017 & 0.005 \\
\hline Potential experience (years) & 22.554 & 21.001 & 23.542 & 23.016 & 23.414 & 19.881 & 23.903 & 23.603 \\
\hline Tenure (years) & 10.255 & 8.507 & 6.938 & 7.167 & 13.338 & 10.291 & 9.015 & 9.293 \\
\hline Non-German (dummy) & 0.044 & 0.031 & 0.007 & 0.007 & 0.053 & 0.041 & 0.011 & 0.007 \\
\hline No apprenticeship, no Abitur (dummy) & 0.028 & 0.045 & 0.011 & 0.009 & 0.038 & 0.058 & 0.016 & 0.013 \\
\hline Apprenticeship, no Abitur (dummy) & 0.759 & 0.703 & 0.789 & 0.694 & 0.613 & 0.598 & 0.734 & 0.712 \\
\hline No apprenticeship, with Abitur (dummy) & 0.005 & 0.010 & 0.004 & 0.002 & 0.012 & 0.024 & 0.005 & 0.005 \\
\hline Apprenticeship and Abitur (dummy) & 0.033 & 0.073 & 0.019 & 0.033 & 0.056 & 0.140 & 0.032 & 0.052 \\
\hline Technical college degree (dummy) & 0.071 & 0.031 & 0.044 & 0.099 & 0.091 & 0.046 & 0.065 & 0.079 \\
\hline University degree (dummy) & 0.049 & 0.043 & 0.045 & 0.049 & 0.137 & 0.102 & 0.109 & 0.095 \\
\hline Education unknown (dummy) & 0.055 & 0.095 & 0.089 & 0.114 & 0.053 & 0.032 & 0.040 & 0.044 \\
\hline Basic manual occupation (dummy) & 0.157 & 0.045 & 0.273 & 0.154 & 0.139 & 0.024 & 0.287 & 0.131 \\
\hline Qualified manual occupation (dummy) & 0.341 & 0.029 & 0.372 & 0.052 & 0.243 & 0.023 & 0.274 & 0.046 \\
\hline Engineer or technician (dummy) & 0.202 & 0.088 & 0.097 & 0.068 & 0.256 & 0.084 & 0.148 & 0.079 \\
\hline Basic service occupation (dummy) & 0.070 & 0.041 & 0.130 & 0.077 & 0.039 & 0.024 & 0.091 & 0.030 \\
\hline Qualified service occupation (dummy) & 0.005 & 0.065 & 0.006 & 0.073 & 0.011 & 0.033 & 0.020 & 0.066 \\
\hline Semi-professional (dummy) & 0.008 & 0.071 & 0.010 & 0.104 & 0.014 & 0.091 & 0.020 & 0.199 \\
\hline Professional (dummy) & 0.007 & 0.022 & 0.007 & 0.018 & 0.017 & 0.032 & 0.021 & 0.035 \\
\hline Basic business occupation (dummy) & 0.043 & 0.146 & 0.024 & 0.132 & 0.024 & 0.126 & 0.017 & 0.060 \\
\hline Qualified business occupation (dummy) & 0.143 & 0.464 & 0.057 & 0.287 & 0.190 & 0.528 & 0.082 & 0.322 \\
\hline Manager (dummy) & 0.024 & 0.029 & 0.025 & 0.035 & 0.067 & 0.034 & 0.039 & 0.032 \\
\hline Log establishment size & 5.531 & 4.971 & 4.523 & 4.631 & 7.945 & 7.329 & 6.133 & 6.004 \\
\hline Collective agreement at sector level (dummy) & 0.521 & 0.403 & 0.262 & 0.166 & 0.726 & 0.719 & 0.586 & 0.531 \\
\hline Collective agreement at firm level (dummy) & 0.112 & 0.083 & 0.135 & 0.113 & 0.218 & 0.173 & 0.203 & 0.268 \\
\hline Works council (dummy) & 0.520 & 0.433 & 0.291 & 0.334 & 0.971 & 0.930 & 0.885 & 0.874 \\
\hline Exporter (dummy) & 0.598 & 0.467 & 0.463 & 0.311 & 0.766 & 0.544 & 0.619 & 0.383 \\
\hline Foreign ownership (dummy) & 0.006 & 0.004 & 0.021 & 0.015 & 0.190 & 0.128 & 0.215 & 0.177 \\
\hline New production technology (dummy) & 0.810 & 0.795 & 0.742 & 0.790 & 0.759 & 0.795 & 0.793 & 0.747 \\
\hline Proportion of female workers & 0.230 & 0.465 & 0.200 & 0.538 & 0.208 & 0.395 & 0.240 & 0.491 \\
\hline Proportion of qualified workers & 0.779 & 0.762 & 0.913 & 0.861 & 0.857 & 0.854 & 0.919 & 0.909 \\
\hline Plant located in rural area (dummy) & 0.272 & 0.246 & 0.448 & 0.325 & 0.105 & 0.115 & 0.313 & 0.290 \\
\hline Agriculture, hunting, forestry (dummy) & 0.006 & 0.010 & 0.020 & 0.018 & 0.000 & 0.000 & 0.006 & 0.005 \\
\hline Mining, quarrying, utilities (dummy) & 0.006 & 0.003 & 0.022 & 0.022 & 0.044 & 0.024 & 0.056 & 0.072 \\
\hline Manufacturing (dummy) & 0.552 & 0.395 & 0.518 & 0.460 & 0.761 & 0.465 & 0.680 & 0.368 \\
\hline Trade and repair (dummy) & 0.116 & 0.200 & 0.085 & 0.099 & 0.038 & 0.102 & 0.031 & 0.039 \\
\hline Construction (dummy) & 0.096 & 0.038 & 0.151 & 0.030 & 0.007 & 0.003 & 0.022 & 0.004 \\
\hline Transport, storage, communication (dummy) & 0.029 & 0.032 & 0.065 & 0.022 & 0.032 & 0.038 & 0.069 & 0.034 \\
\hline Financial intermediation (dummy) & 0.006 & 0.007 & 0.001 & 0.003 & 0.049 & 0.144 & 0.006 & 0.017 \\
\hline Business activities (dummy) & 0.166 & 0.146 & 0.097 & 0.077 & 0.040 & 0.071 & 0.066 & 0.125 \\
\hline Other activities (dummy) & 0.023 & 0.170 & 0.042 & 0.269 & 0.028 & 0.153 & 0.065 & 0.336 \\
\hline Number of workers & 40,235 & 12,128 & 21,188 & 8,493 & 234,164 & 56,152 & 45,061 & 19,756 \\
\hline
\end{tabular}

Notes: The data set used is the LIAB cross-sectional model for the year 2007 
Table 6 Unexplained gender pay gaps obtained from separate Oaxaca-Blinder decompositions for workers employed by manager- and owner-run plants (matched sample; matching on plant size only; in log points)

\begin{tabular}{llll}
\hline & Overall & Owner-run & Manager-run \\
\hline West Germany & $22.6(1.2)$ & $27.7(1.5)$ & $18.6(1.4)$ \\
& {$[20.2,24.9]$} & {$[24.7,30.8]$} & {$[15.8,21.4]$} \\
East Germany & $19.5(1.6)$ & $21.7(2.4)$ & $16.2(2.3)$ \\
& {$[16.2,22.7]$} & {$[16.9,26.4]$} & {$[11.7,20.8]$} \\
\hline
\end{tabular}

Notes: The data set used is the LIAB cross-sectional model for the year 2007. Standard errors clustered at the plant level are given in parentheses followed from 95 per cent confidence intervals. Control variables included are those reported in the notes of Table 2

\section{References}

Achatz, J., Gartner, H., Glück, T.: Bonus oder bias? Mechanismen geschlechtsspezifischer Entlohnung. Köln. Z. Soziol. Soz.psychol. 57(3), 466-493 (2005)

Alda, H., Bender, S., Gartner, H.: The linked employer-employee dataset created from the IAB establishment panel and the processproduced data of the IAB (LIAB). Schmollers Jahrb. Wirtsch.Soz.wiss. 125(2), 327-336 (2005)

Arrow, K.J.: The theory of discrimination. In: Ashenfelter, O.C., Rees, A. (eds.) Discrimination in Labor Markets, pp. 3-33. Princeton University Press, Princeton (1973)

Ashenfelter, O.C., Hannan, T.: Sex discrimination and product market competition: the case of the banking industry. Q. J. Econ. 101(1), 149-174 (1986)

Beblo, M., Ohlert, C., Wolf, E.: Logib-D und die Entgeltunterschiede zwischen Männern und Frauen in deutschen Betrieben - Eine Abschätzung des politischen Handlungsfeldes. J. Labour Mark. Res. 44(1), 43-52 (2011)

Becker, G.S.: The Economics of Discrimination, 2nd edn. University of Chicago Press, Chicago (1971)

Bender, S., Haas, A., Klose, C.: The IAB employment subsample 1975-95. Schmollers Jahrb. Wirtsch.- Soz.wiss. 120(4), 649-662 (2000)

Benz, M.: Entrepreneurship as a non-profit-seeking activity. Int. Entrepreneurship Manage. J. 5(1), 23-44 (2009)

Benz, M., Frey, B.S.: Being independent is a great thing: subjective evaluations of self-employment and hierarchy. Economica 75(298), 362-383 (2008)

Berle, A.A., Means, G.C.: The Modern Corporation and Private Property. Macmillan, New York (1932)

Black, S.E., Strahan, P.E.: The division of spoils: rent-sharing and discrimination in a regulated industry. Am. Econ. Rev. 91(4), 814 831 (2001)

Bowlus, A.J., Eckstein, Z.: Discrimination and skill differences in an equilibrium search model. Int. Econ. Rev. 43(4), 1309-1345 (2002)

Cardoso, A.R., Winter-Ebmer, R.: Female-led firms and gender wage policies. Ind. Labor Relat. Rev. 64(1), 143-163 (2010)

Chevalier, A.: Education, occupation and career expectations. Oxf. Bull. Econ. Stat. 69(6), 819-842 (2007)
Demsetz, H.: The structure of ownership and the theory of the firm. J. Law Econ. 26(2), 375-390 (1983)

European Commission: Report on Equality Between Women and Men 2010. European Commission, Luxembourg (2010)

Fischer, G., Janik, F., Müller, D., Schmucker, A.: The IAB establishment panel-things users should know. Schmollers Jahrb. Wirtsch.- Soz.wiss. 129(1), 133-148 (2009)

Gartner, H.: The imputation of wages above the contribution limit with the German IAB employment sample. Forschungsdatenzentrum des Instituts für Arbeitsmarkt- und Berufsforschung, Methodenreport Nr. 2/2005. Nürnberg (2005)

Hamilton, B.H.: Does entrepreneurship pay? An empirical analysis of the returns to self-employment. J. Polit. Econ. 108(3), 604-631 (2000)

Heinze, A., Wolf, E.: The intra-firm gender wage gap: a new view on wage differentials based on linked employer-employee data. J. Popul. Econ. 23(3), 851-879 (2010)

Hellerstein, J.K., Neumark, D., Troske, K.R.: Market forces and sex discrimination. J. Hum. Resour. 37(2), 353-380 (2002)

Heyman, F., Svaleryd, H., Vlachos, J.: Competition, takeovers, and gender discrimination. Ind. Labor Relat. Rev. 66(2), 409-432 (2013)

Hirsch, B.: The impact of female managers on the gender pay gap: evidence from linked employer-employee data for Germany. Econ. Lett. 119(3), 348-350 (2013)

Hirsch, B., Schnabel, C.: Women move differently: job separations and gender. J. Labor Res. 33(4), 417-442 (2012)

Hirsch, B., Oberfichtner, M., Schnabel, C.: Do women profit from competitive markets? Product market competition and the gender pay gap in Germany. Econ. Bull. 32(2), 1618-1624 (2012)

Kawaguchi, D.: A market test for sex discrimination: evidence from Japanese firm-level panel data. Int. J. Ind. Organ. 25(3), 441-460 (2007)

Kölling, A.: The IAB-establishment panel. Schmollers Jahrb. Wirtsch.Soz.wiss. 120(2), 291-300 (2000)

Lazear, E.P.: Personnel Economics. MIT Press, Cambridge (1995)

Maier, F.: The persistence of the gender wage gap in Germany, Harriet Taylor Mill-Institut für Ökonomie und Geschlechterforschung. Discussion paper 01-2007, Berlin (2007)

Méon, P.G., Szafarz, A.: The modern corporation as a safe haven for taste-based discrimination: an agency model of hiring decisions. Labour Econ. 18(4), 487-497 (2011)

Mortensen, D.T.: Equilibrium wage distributions: a synthesis. In: Hartog, J., Ridder, G., Theeuwes, J. (eds.) Panel Data and Labor Market Studies, pp. 279-296. Elsevier, Amsterdam (1990)

Murphy, K.J.: Executive compensation. In: Ashenfelter, O.C., Card, D.E. (eds.) Handbook of Labor Economics, vol. 3B, pp. 24852563. Elsevier, Amsterdam (1999)

Oaxaca, R.L., Ransom, M.R.: On discrimination and the decomposition of wage differentials. J. Econom. 61(1), 5-21 (1994)

Oi, W.Y., Idson, T.L.: Firm size and wages. In: Ashenfelter, O.C., Card, D.E. (eds.) Handbook of Labor Economics, vol. 3B, pp. 2165 2214. Elsevier, Amsterdam (1999)

Vroom, G., McCann, B.T.: Ownership structure, profit maximisation, and competitive behavior. University of Navarra, IESE Business School, Navarra, Working paper No. 800 (2010)

Weichselbaumer, D., Winter-Ebmer, R.: A meta-analysis of the international gender wage gap. J. Econ. Surv. 19(3), 479-511 (2005)

Winter-Ebmer, R.: Sex discrimination and competition in product and labour markets. Appl. Econ. 27(9), 849-857 (1995)

Zweimüller, M., Winter-Ebmer, R., Weichselbaumer, D.: Market orientation and gender wage gaps: an international study. Kyklos 61(4), 615-635 (2008) 
Dr. Boris Hirsch studied economics and mathematics at the University of Erlangen-Nuremberg and the University of Hagen. In 2009, he received his $\mathrm{PhD}$ in economics from the University of ErlangenNuremberg. Since October 2006, he has been working as a researcher at the Chair of Labour and Regional Economics at the University of Erlangen-Nuremberg. His research focuses on empirical labour economics, industrial relations, and migration.
Dr. Steffen Mueller studied economics at the University of Leipzig. In 2009, he received his $\mathrm{PhD}$ in economics from the University of Erlangen-Nuremberg. Since September 2005, he has been working as a researcher at the Chair of Statistics and Empirical Economic Research at the University of Erlangen-Nuremberg. His research focuses on empirical labour economics, education economics, and industrial relations. 